\title{
KEDUDUKAN HUKUM NOKEP 883-DIR/KPS/10/2012 SEBAGAI DASAR PEMBERIAN HAK PENSIUN BAGI PEKERJA PT BRI PERSERO TBK
}

\author{
Asri Wijayanti \\ Fakultas Hukum Universitas Muhammadiyah Surabaya \\ e-mail: asri1wj@yahoo.com
}

\begin{abstract}
ABSTRAK
Sebelum disahkannya Undang-Undang Nomor 13 Tahun 2003 tentang Ketenagakerjaan, pekerja yang diberhentikan karena memasuki usia pensiun, mendapat hak atas dana pensiun (bagi pegawai negeri) atau hak atas pesangon (bagi pekerja swasta). Kedudukan SK Direksi Nokep 883-DIR/KPS/10/2012 yang dianalisis berdasarkan Pasal 167 Undang-Undang Nomor 13 Tahun 2003 tentang Ketenagakerjaan, telah mengikutsertakan pekerja dalam program pensiun yang iuran atau preminya dibayar oleh PT BRI Persero Tbk dan pekerja. Substansi SK Direksi Nokep 883-DIR/KPS/10/2012 telah melanggar Pasal 167 ayat (3) Undang-Undang Nomor 13 Tahun 2003 tentang Ketenagakerjaan.
\end{abstract}

Kata Kunci: hak pensiun, hak pesangon, premi, PT BRI Persero Tbk.

\begin{abstract}
Prior to the enactment of Law 13/2003, workers whose did dismissal due to retirement, the right to receive pension funds (for civil servants) or rights to severance pay (for private sector workers). The aim of the article to provide an alternative solution for the national case on retired PT BRI Persero Tbk on going at this time, Status of Directors Nokep 883-DIR/KPS/10/2012 SK analyzed based on Article 167 Law 13/2003, this is BRI has included workers/employees in the pension plans whose contributions/premiums paid by the BRI and workers. SK Nokep 883-DIR/KPS/10/2012 Directors has violated Article 167 paragraph (3) of Law 13/2003.
\end{abstract}

Keywords: pension rights, severance entitlements, premium, BRI.

\section{PENDAHULUAN}

Negara Kesatuan Republik Indonesia adalah negara yang mempunyai penduduk yang terbanyak keempat di dunia. Berdasarkan sensus penduduk tahun 2010, jumlah penduduk Indonesia adalah 237.641 .326 orang ( http:// www.bps.go.id/tab_sub/ view.php?tabel=1\&id_subyek=12). Tentunya, dengan jumlah penduduk yang sangat banyak itu, dibutuhkanlah lapangan kerja yang memadai. Pada bulan Agustus 2013, jumlah angkatan kerja adalah 118,2 juta orang. Jumlah penduduk yang bekerja sejumlah 110,8 juta orang (Berita Resmi Statistik, 2013:1). Banyaknya penduduk yang bekerja, diiringi banyaknya kasus ketenagakerjaan. Banyaknya kasus pelanggaran hak dasar pekerja menunjukkan belum adanya perlindungan hukum bagi pekerja secara maksimal. Perjuangan pekerja memperoleh hak-hak normatif masih berlangsung hingga sekarang.
Kurangnya perlindungan hukum hampir di semua bidang pekerjaan, lemahnya perlindungan hukum bagi pekerja kontrak karena hampir tidak pernah ada yang didaftarkan ke Dinas Tenaga Kerja dan Transmigrasi Penduduk (selanjutnya disebut Disnakertransduk). Adanya kebohongan pada alasan pemutusan hubungan kerja, belum adanya batasan tentang norma pelanggaran. Bagi Tenaga Kerja Indonesia (selanjutnya disingkat TKI), perjanjian kerjanya belum dapat menjamin perlindungan hukum. Kendala terbesar perlindungan TKI pada saat penempatan karena tunduk pada kedaulatan teritorial negara penempatan. Sebagai tujuan pekerja bekerja yaitu upah, masih sangat belum terlindungi, misalnya majikan enggan untuk meningkatkan atau menaikkan upah pekerja meskipun terjadi peningkatan hasil produksi dengan dalih bahwa takut diprotes oleh 
perusahaan-perusahaan lain yang sejenis. Besarnya Upah Minimum Kerja (yang selanjutnya disingkat UMK) rata-rata di Indonesia di bawah standar upah internasional. Akibatnya Indonesia dituding sebagai suatu negara yang melakukan dumping berkaitan dengan rendahnya upah pekerja dalam percaturan perdagangan bebas. Kesalahan menafsirkan besarnya pesangon pada Pemutusan Hubungan Kerja (yang selanjutnya disebut PHK) karena adanya perubahan atau PHK karena memasuki masa pensiun.

Kasus setelah masa pensiun, juga terjadi pada pekerja yang bekerja pada Badan Usaha Milik Negara (selanjutnya disebut BUMN). Salah satu BUMN yang ada di Indonesia adalah Bank Rakyat Indonesia (selanjutnya disebut PT BRI Persero Tbk). Hubungan hukum yang terjadi antara PT BRI Persero Tbk dengan pekerjanya adalah hubungan kerja. Setiap hubungan kerja harus didasarkan pada aturan hukum yang berlaku di Indonesia. Demikian pula dengan hubungan kerja antara pekerja PT BRI Persero Tbk dengan PT BRI Persero Tbk juga dilindungi oleh hukum. Pekerja PT BRI Persero Tbk yang telah diputus hubungan kerjanya karena telah memasuki usia pensiun, merasa belum mendapatkan hak yang seharusnya seperti yang telah diatur dalam UndangUndang Nomor 13 Tahun 2003 tentang Ketenagakerjaan (selanjutnya disingkat UU Ketenagakerjaan). Pekerja beranggapan bahwa belum ada aturan yang jelas atau terbuka di PT BRI Persero Tbk berkaitan dengan hak pekerja yang di PHK karena memasuki usia pensiun. Gugatan telah dilakukan oleh Pekerja PT BRI Persero Tbk. Gugatan pertama yang dilakukan oleh pekerja PT BRI Persero Tbk terjadi di Sumatera Utara. Kasus ini sudah diputus oleh Mahkamah Agung (selanjutnya disingkat MA). Ternyata kasus tersebut telah menjadi motivasi perjuangan untuk memperoleh hak bagi pekerja PT BRI Persero Tbk di wilayah selain Sumatera Utara.

Hak pekerja dijamin dan dilindungi oleh aturan hukum. Secara konstitusional, hak pekerja dijamin dalam Pasal 27 ayat (1) dan (2) UUD 1945, yang menyatakan, segala warga negara bersamaan kedudukannya di dalam hukum dan pemerintahan dan wajib menjunjung hukum dan pemerintahan itu dengan tidak ada kecualinya, dan tiap-tiap warga negara berhak atas pekerjaan dan penghidupan yang layak bagi kemanusiaan. Warga negara yang bekerja mendapat perlindungan secara konstitusional berdasarkan Pasal 27 ayat (1) jo (2) UUD 1945. Implementasinya diatur lebih lanjut berdasarkan UU Ketenagakerjaan (Lembaran Negara Tahun 2003 Nomor 39, Tambahan Lembaran Negara Tahun 2003 Nomor 4279).

Perlindungan terhadap pekerja yang mengalami pemutusan hubungan kerja terdapat dalam Bab XII tentang PHK (Pasal 150-172 UU Ketenagakerjaan). PHK karena memasuki usia pensiun dilindungi oleh Pasal 167 UU Ketenagakerjaan. Dalam kasus PHK bagi pekerja karena memasuki usia pensiun di PT BRI Persero Tbk telah terjadi perbedaan pendapat antara pekerja dan PT BRI Persero Tbk. Pekerja berpendapat bahwa mereka belum mendapatkan hak sesuai dengan ketentuan Pasal 167 UU Ketenagakerjaan. PT BRI Persero Tbk berpendapat bahwa pekerja sudah mendapatkan hak sesuai dengan ketentuan Pasal 167 UU Ketenagakerjaan. Pemberian hak didasarkan pada ketentuan SK Direksi Nokep 883-DIR/KPS/ 10/2012. Menurut pekerja, terdapat rekayasa oleh BRI tercantum pada Pasal 4 ayat 2 SK Direksi BRI Nomor 883-DIR/KPS/10/2012 tanggal 1 Oktober 2012 tentang penjelasan atau definisi Program Pensiun Manfaat Pasti (selanjutnya disebut PPMP) (http:// news.detik.com/surabaya/read/2013/03/19/120336/ 2197760/466/pensiunan-demo-inilah-penjelasanmanajemen-bri).

\section{PERUMUSAN MASALAH}

Dari uraian di atas, maka permasalahannya bagaimana kedudukan Hukum SK Direksi Nokep 883-DIR/KPS/10/2012 sebagai dasar pemberian hak pensiun bagi pekerja PT BRI Persero Tbk.

\section{METODE PENELITIAN}

Metode penelitian yang digunakan adalah yuridis normatif dengan pendekatan statute approach dan case approach. Bahan hukum yang digunakan dalam penelitian ini adalah peraturan perundang-undangan yang mengatur tentang hak pekerja yang di PHKnya karena memasuki usia pensiun beserta putusan pengadilan yang berkaitan dengan itu.

\section{PEMBAHASAN}

Bank Rakyat Indonesia (selanjutnya disebut BRI) merupakan salah satu bank milik pemerintah yang terbesar di Indonesia. Pada awalnya BRI didirikan di Purwokerto, Jawa Tengah oleh Raden Bei Aria Wirjaatmadja_dengan nama De Poerwokertosche Hulp en Spaarbank der Inlandsche Hoofden (http: //id.wikipedia.org/wiki/Bank_Rakyat_Indonesia) atau 
Bank Bantuan dan Simpanan Milik Kaum Priyayi Purwokerto, suatu lembaga keuangan yang melayani orang-orang berkebangsaan Indonesia (pribumi). Lembaga tersebut berdiri tanggal 16 Desember 1895 , yang kemudian dijadikan sebagai hari kelahiran BRI (http://ir-bri.com/)

Periode setelah Kemerdekaan RI, berdasarkan Peraturan Pemerintah Nomor 1 Tahun 1946 Pasal 1 disebutkan bahwa BRI merupakan bank pemerintah pertama di Republik Indonesia. Dalam masa perang mempertahankan kemerdekaan pada tahun 1948, kegiatan BRI sempat terhenti untuk sementara waktu dan baru mulai aktif kembali setelah Perjanjian Renville pada tahun 1949, dengan berubah nama menjadi Bank Rakyat Indonesia Serikat. Pada waktu itu melalui PERPU No. 41 Tahun 1960 dibentuklah Bank Koperasi Tani dan Nelayan (selanjutnya disebut BKTN) yang merupakan peleburan dari BRI, Bank Tani Nelayan dan Nederlandsche Maatschappij (NHM). Berdasarkan Penetapan Presiden Nomor 9 Tahun 1965, BKTN diintegrasikan ke dalam Bank Indonesia dengan nama Bank Indonesia Urusan Koperasi Tani dan Nelayan.

Setelah berjalan selama satu bulan, keluar Penetapan Presiden Nomor 17 Tahun 1965 tentang Pembentukan Bank Tunggal dengan nama Bank Negara Indonesia. Dalam ketentuan baru itu, Bank Indonesia Urusan Koperasi, Tani dan Nelayan (eks BKTN) diintegrasikan dengan nama Bank Negara Indonesia unit II bidang Rural, sedangkan NHM menjadi Bank Negara Indonesia Unit II bidang Ekspor Impor (Exim).

Berdasarkan Undang-Undang Nomor 14 Tahun 1967 tentang Undang-Undang Pokok Perbankan dan Undang-Undang Nomor 13 Tahun 1968 tentang UndangUndang Bank Sentral, yang intinya mengembalikan fungsi Bank Indonesia sebagai Bank Sentral dan Bank Negara Indonesia Unit II Bidang Rular dan Ekspor Impor dipisahkan masing-masing menjadi dua Bank yaitu Bank Rakyat Indonesia dan Bank Ekspor Impor Indonesia. Selanjutnya berdasarkan Undang-Undang Nomor 21 Tahun 1968 menetapkan kembali tugastugas pokok BRI sebagai bank umum.

Sejak 1 Agustus 1992 berdasarkan UndangUndang Perbankan Nomor 7 tahun 1992 dan Peraturan Pemerintah RI Nomor 21 Tahun 1992 status BRI berubah menjadi Perseroan Terbatas. Kepemilikan BRI saat itu masih 100\% di tangan Pemerintah Republik Indonesia. Pada tahun 2003, Pemerintah Indonesia memutuskan untuk menjual 30\% saham bank ini, sehingga menjadi perusahaan publik dengan nama resmi PT Bank Rakyat Indonesia (Persero) Tbk, yang masih digunakan sampai dengan saat ini.

Sampai saat ini PT BRI Persero Tbk yang didirikan sejak tahun 1895 tetap konsisten memfokuskan pada pelayanan kepada masyarakat kecil, diantaranya dengan memberikan fasilitas kredit kepada golongan pengusaha kecil. Hal ini antara lain tercermin pada perkembangan penyaluran Kredit Usaha Kecil (KUK) pada tahun 1994 sebesar Rp. 6.419,8 milyar yang meningkat menjadi Rp. 8.231,1 milyar pada tahun 1995 dan pada tahun 1999 sampai dengan bulan September sebesar Rp. 20.466 milyar. Seiring dengan perkembangan dunia perbankan yang semakin pesat maka sampai saat ini, Bank Rakyat Indonesia mempunyai unit kerja yang berjumlah 4.447 buah, yang terdiri dari 1 Kantor Pusat BRI, 12 Kantor Wilayah, 12 Kantor Inspeksi/SPI, 170 Kantor Cabang dalam negeri, 145 Kantor Cabang Pembantu, 1 Kantor Cabang Khusus, 1 New York Agency, 1 Caymand Island Agency, 1 Kantor Perwakilan Hongkong, 40 Kantor Kas Bayar, 6 Kantor Mobil Bank, 193 P.POINT, 3.705 BRI UNIT dan 357 Pos Pelayanan Desa (http://id.wikipedia.org/ wiki/Bank_Rakyat_Indonesia). Perkembangan PT BRI Persero Tbk dalam perbankan sampai tahun 2012, telah menghasilkan net profit sebesar Rp. 18,69 Trilyun (http://media.corporate-ir.net/media_files/IROL/14/ 148820/AR_BRI_Englis_2012.pdf)

\section{Analisa SK Nokep 883-DIR/KPS/10/2012 terhadap Pasal 167 UU Ketenagakerjaan}

Tuntutan hak atas PHK karena memasuki usia pensiun oleh Forum Komunikasi Pensiunan BRI Perjuangan Pesangon (FKP3) Wilayah Jawa Timur. Hubungan hukum antara PT BRI Persero Tbk dan pekerjanya adalah hubungan kerja yang tunduk pada UU Ketenagakerjaan. Bagi pekerja yang diputus hubungan kerjanya karena memasuki usia pensiun, mendapatkan hak berdasarkan ketentuan Pasal 167 UU Ketenagakerjaan.

Telah berkembang perdebatan di masyarakat, mengenai hak pekerja yang di PHK karena memasuki usia pensiun. Apakah mereka mendapat pesangon ataukah tidak. Dana pensiun semula dikenal bagi pegawai negeri atau mereka yang bekerja di perusahaan milik negara. Sementara bagi pekerja yang bekerja di perusahaan swasta, berhak atas pesangon. Bagi pensiun-pegawai dan pensiun-janda/duda diberikan 
sebagai jaminan hari tua dan sebagai penghargaan atas jasa-jasa pegawai negeri selama bertahun-tahun bekerja dalam dinas pemerintah (Pasal 1 angka 1 Undang-Undang Nomor 11 Tahun 1969 tentang Pensiun Pegawai dan Pensiun Janda/Duda Pegawai). Besarnya pensiun ditentukan berdasarkan gaji pokok terakhir yang diterimanya (Pasal 5 Undang-Undang Nomor 11 Tahun 1969).

Kasus pembelian aset PT Tahta Medan milik Dana Pensiun Bank Mandiri (DPBM) III oleh PT Cipta Graha Nusantara (CGN) sangat menguntungkan DPBM III dan memenuhi seluruh prosedur formal. Pembelian itu bisa dikatakan telah menyelamatkan DPBM III dari kerugian yang dialami sejak 1979 (http://www.antikorupsi.org/id/content/sidang-kasuskorupsi-pt-cgn-selamatkan-dana-pensiun-bank-mandiriiii). Kasus serupa juga terjadi pula pada pekerja yang di PHK karena memasuki usia pensiun di PT BRI Persero Tbk. Pensiunan PT BRI Persero Tbk, merasa adanya pelanggaran hak pesangon. Karena itulah terjadi gugatan oleh pensiunan PT BRI Persero Tbk, kepada PT BRI Persero Tbk, di Pengadilan Hubungan Industrial Medan (http://kennortonhs.wordpress.com/2007/08/02/ sejumlah-pensiunan-bri-tuntut-pesangon). Atas gugatan tersebut diputuslah Putusan MA No. 568K/Pdt.Sus/ 2009. Putusan itu telah mempunyai kekuatan hukum yang tetap, dengan menolak permohonan pensiunan PT BRI Persero Tbk Medan.

Perlawanan pensiunan PT BRI Persero Tbk sampai sekarang masih berlangsung di wilayah selain Medan di seluruh Indonesia (http://jakarta.okezone.com/read/ 2013/09/04/500/860896/direct). Perkembangan terakhir adanya tuntutan agar Menakertrans mengeluarkan Juklak atas kasus ini (http://jakarta.okezone.com/ $\mathrm{read} / 2013 / 10 / 07 / 500 / 877648 /$ direct).

PT BRI Persero Tbk belum memberikan informasi yang lengkap dan terbuka mengenai dasar perhitunggan pemberian dana pensiun kepada pekerja yang di PHK tanggal 30 Maret 2003 sampai dengan 1 Desember 2012 karena memasuki usia pensiun. Ketidakterbukaan PT BRI Persero Tbk menjadi bukti bahwa kinerja PT BRI Persero Tbk, sebagai salah satu bentuk BUMN belum maksimal menerapkan keterbukaan dalam pengelolaan manajemennya. Menurut Wicaksono, BUMN di Indonesia secara umum mengalami problem yaitu conflicting objectives, agency issue (political interference) dan lack of transparency adalah tiga problem utama badan usaha milik negara di dunia. Indonesia juga menghadapi masalah yang sama.
Conflicting objectives maksudnya BUMN tidak hanya memiliki tujuan komersial tapi juga memikul beban pemenuhan kepentingan sosial seperti penyediaan lapangan kerja, pelayanan kepentingan masyarakat dan menyediakan kebutuhan dasar. Dengan kata lain, tidak sebagaimana perusahaan pribadi, BUMN memiliki tanggung jawab memenuhi kepentingan masyarakat banyak di samping tugas mencari keuntungan. Disebabkan oleh multi tugas tersebut, BUMN berada pada posisi yang kurang menguntungkan dalam hal berkompetisi dengan perusahaan-perusahaan swasta murni dalam meraup keuntungan. Meskipun negara yang diwakili oleh pemerintah dan masyarakat awam dapat diklasifikasikan sebagai pemilik BUMN, dilihat dari sisi agency teori, kepemilikan BUMN adalah kabur, pemerintah disebut sebagai pemilik karena pemerintah adalah penyedia modal; sedangkan masyarakat terkategori sebagai pemilik karena mereka memberikan uang kepada pemerintah dalam bentuk pembayaran pajak (tax payers). Dalam praktiknya, politisi dan birokrat adalah wakil dari pemerintah dan juga masyarakat awam dalam menjaga operasional BUMN. Konsekuensinya, sejumlah politisi dan birokrat menjabat sebagai anggota pengurus BUMN, terutama dewan komisaris. Berkenaan dengan lack of transparency, maksudnya adalah kecenderungan BUMN menutup informasi-informasi penting kepada masyarakat sebagai pemilik BUMN. Oleh karena itu, masyarakat tidak bisa melakukan control. Lack of transparency sepertinya adalah agenda terencana yang dirancang para pemilik aktual BUMN (politisi dan birokrat). Diduga, hal ini terjadi karena mereka berusaha menutupi agenda-agenda pribadi di bisnis BUMN.

Lack of transparency juga menyebabkan BUMN menjadi perusahaan yang tidak efisien. salah satu isu kontemporer perusahaan-perusahaan di Indonesia secara umum adalah komisaris yang tidak profesional. Buruknya kinerja perusahaan-perusahaan Indonesia diduga disebabkan oleh tidak profesionalnya komisaris dalam menjalankan tugas-tugasnya.

Komisaris profesional tidak eksis di Indonesia, khususnya di BUMN PT tertutup, karena sebagian besar komisaris adalah orang-orang sibuk seperti politisi, pensiunan tentara atau polisi, mantan menteri dan pejabat tinggi negara semisal Sekretaris atau Direktur Jenderal di sebuah kementrian (Wicaksono 2009: 149-156). Kekaburan pemilik BUMN menyuburkan terjadinya intervensi politik terhadap BUMN (Miko 
Kamal, 2011:151). Fakta yang ada, terdapat perbedaan nilai kompensasi pensiun antar pekerja yang memiliki jenjang dan masa kerja yang sama (Wawancara tak terstruktur dengan pensiunan PT BRI Persero Tbk wilayah Jawa Timur tanggal 10 Oktober 2013).

Berbagai upaya dilakukan untuk menyelesaikan perselisihan ini. PT BRI Persero Tbk telah mengeluarkan SK Direksi Nokep 883-DIR/KPS/10/2012 tentang Penyelesaian Kewajiban Perusahaan terhadap pekerja yang berakhir hubungan kerjanya karena mencapai usia pensiun normal sebagai implementasi dari UU Ketenagakerjaan tanggal 1 Oktober 2012.

Keberadaan SK Direksi Nokep 883-DIR/KPS/10/ 2012 justru menimbulkan perselisihan semakin tajam. Terdapat perbedaan interpretasi antara PT BRI Persero Tbk dan pensiunan BRI mengenai penerapan Pasal 167 UU Ketenagakerjaan dalam SK Direksi Nokep 883-DIR/KPS/10/2012. Sampai dengan saat tulisan ini dibuat, upaya penyelesaian telah memasuki mediasi. Hasil mediasi berdasarkan Surat Majelis Mediator Hubungan Industrial Disnakertransduk Propinsi Jawa Timur No. 560/434/106.04/2013 tanggal 9 Oktober 2013 adalah: Pertama, Agar pihak perusahaan PT BRI Persero Tbk membayar kekurangan upah untuk tahun 2003 dan tahun 2004 kepada pihak pekerja Sdr. H. Ahmad Djauhari, dkk (799 orang) yang tergabung dalam Forum Komunikasi Pensiunan BRI Perjuangan Pesangon (FKP3) Wilayah Jawa Timur; dan Kedua, Agar pihak perusahaan PT BRI Persero Tbk membayar kekurangan uang pesangon, uang penghargaan masa kerja dan hak-hak lain yang timbul kepada pihak pekerja Sdr. H. Ahmad Djauhari, dkk (799 orang) yang tergabung dalam Forum Komunikasi Pensiunan BRI Perjuangan Pesangon (FKP3) Wilayah Jawa Timur.

Secara universal, hak pekerja merupakan bagian dari hak asasi manusia. Hak merupakan konsep yuridis, mengandung batasan hak dan kewajiban. Hak berasal dari kata right, artinya something (as a power or privilege) to which one has a just or lawful claim (The Merriam Webster Dictionary, 2004:626). Paton menyebutkan hak mengandung tiga elemen yaitu protection, will, dan interest (G.W. Paton, 1964:286). Inti yang terkandung di dalam hak, yaitu adanya suatu tuntutan (claim) (Philipus M. Hadjon, 2007:34). Claim merupakan suatu upaya hukum yang dapat dilakukan, apabila terdapat hak yang dilanggar. Hak dibedakan menjadi empat yaitu hak dalam arti sempit (setiap hak akan berhadapan dengan kewajiban), kebebasan (melahirkan ketidakbebasan), kekuasaan (berhadapan dengan pertanggungjawaban), dan kekebalan (hubungannya dengan ketidakmampuan) (Lili Rasjidi, 1988:76-77).

The Universal Declaration of Human Rights (UD of HR atau Piagam PBB). Berdasarkan Pasal 3 Piagam PBB menyatakan bahwa Everyone has the right to life, liberty and security of person (Setiap orang berhak atas kehidupan, kemerdekaan dan keamanan pribadi). Pasal ini merupakan tonggak pertama, deklarasi menyatakan hak untuk hidup, kebebasan dan keamanan seseorang suatu hak yang esensial untuk pemenuhan hak-hak lainnya. Pasal 3 Piagam PBB menjadi dasar perlindungan hukum atas hak asasi pekerja di seluruh dunia, termasuk pekerja PT BRI Persero Tbk.

PT BRI Persero Tbk telah mengeluarkan SK Direksi Nokep 883-DIR/KPS/10/2012 tentang Penyelesaian Kewajiban Perusahaan terhadap Pekerja yang Berakhir Hubungan Kerjanya karena Mencapai Usia Pensiun Normal sebagai implementasi dari UU Ketenagakerjaan tanggal 1 Oktober 2012. SK Direksi Nokep 883-DIR/KPS/10/2012 diedarkan ke seluruh pemimpin cabang khusus dan pemimpin cabang PT BRI Persero Tbk berdasarkan Surat Divisi Kebijakan dan Pengembangan SDM PT BRI Persero Tbk No. B.355-KPS/HBI/10/2012 tanggal 11 Oktober 2012 untuk menginformasikan SK Direksi Nokep 883 DIR/KPS/10/2012 dan Juklaknya kepada pekerja BRI yang di PHK karena mencapai usia pensiun normal terhitung mulai tanggal 31 Maret 2003 sampai dengan 31 Desember 2011.

Atas dasar SK Direksi Nokep 883-DIR/KPS/10/ 2012, PT BRI Persero Tbk secara profesional telah memberikan hak para pekerjanya. Para pekerja dianggap telah menerima haknya, program pensiun yang iuran preminya dibayar penuh oleh perusahaan, maka pekerja tidak berhak atas uang pesangon (http:// www.jpnn.com/read/2013/09/04/189305/BRI-DianggapProfesional-Penuhi-Hak-Pensiunan).

PT BRI Persero Tbk telah melakukan pembayaran kompensasi untuk 5.953 pensiunan dengan total pembayaran plus pajak sebesar Rp. 27,5 miliar, Total pensiunan antara jangka waktu tersebut sebanyak 7.555 orang. Sebanyak 5.935 tidak mendapatkan uang kompensasi karena dana pensiunnya sudah sesuai dengan perhitungan. Sementara sisanya sebanyak 667 orang masih akan dilakukan perhitungan dan pembayaran (http://m.news.viva.co.id/news/read/ 429287-gelar-demo-ada-apa-dengan-pensiunan-bri). 
Saat ini, total karyawan BRI mencapai 100 ribu orang, dengan 20 ribu di antaranya merupakan karyawan alih daya (outsourcing), yaitu petugas keamanan dan pengemudi (supir). Dari 80 ribu karyawan nonoutsourcing, sebanyak 50 ribu merupakan peserta Dana Pensiun BRI, sehingga 30 ribunya belum menjadi peserta.

Dari total peserta Dapen BRI sebanyak 50 ribu tersebut, sebanyak 20 ribu diantaranya telah pensiun dan sisanya belum pensiun. Setiap tahunnya, Dapen BRI membayar pensiunan sekitar Rp 550 miliar. Sedangkan setiap tahun, total pensiunan bertambah sekitar 1.200 orang, dari total karyawan BRI saat ini sekitar 100 ribu orang (http://www.beritasatu.com/ nasional/113436-demo-pensiunan-bri-tetap-pegangkeputusan-ma.html).

SK Direksi Nokep 883-DIR/KPS/10/2012 adalah salah satu bentuk dari peraturan perusahaan. Berdasarkan ketentuan Pasal 1 angka 20 UU Ketenagakerjaan, peraturan perusahaan adalah peraturan yang dibuat secara tertulis oleh pengusaha yang memuat syaratsyarat kerja dan tata tertib perusahaan. Selanjutnya pengaturan mengenai Peraturan Perusahaan terdapat dalam Pasal 108-111 UU Ketenagakerjaan. Peraturan perusahaan sekurang-kurangnya memuat: hak dan kewajiban pengusaha; hak dan kewajiban pekerja/ pekerja; syarat kerja; tata tertib perusahaan; dan jangka waktu berlakunya peraturan perusahaan (Pasal 111 ayat (1) UU Ketenagakerjaan). Ketentuan dalam peraturan perusahaan tidak boleh bertentangan dengan ketentuan peraturan perundang undangan yang berlaku (Pasal 111 ayat (2) UU Ketenagakerjaan).

SK Direksi Nokep 883-DIR/KPS/10/2012 adalah bentuk dari peraturan perusahaan sehingga isi atau muatannya tidak boleh bertentangan dengan Perjanjian Kerja Bersama (selanjutnya disebut PKB) dan peraturan perundang-undangan (diantaranya UU Ketenagakerjaan). Atas dasar ketentuan Pasal 111 ayat (2) UU Ketenagakerjaan inilah maka perlu dilakukan analisis tentang substansi SK Direksi Nokep 883-DIR/KPS/10/2012.

Analisis Substansi SK Nokep 883-DIR/KPS/ 10/2012 terhadap Pasal 167 UU Ketenagakerjaan berdasarkan substansi subyek terdapat tiga problem hukum berkaitan dengan substansi subyek:

Pertama, berkaitan dengan tanggal dikeluarkannya SK. Subyek hukum berkaitan SK Direksi Nokep 883-DIR/KPS/10/2012 pada dasarnya ada dua yaitu PT BRI Persero Tbk dan pekerja PT BRI Persero
Tbk. SK Direksi Nokep 883-DIR/KPS/10/2012 ini dikeluarkan pada tanggal 1 Oktober 2012. Hal ini menjadikan SK Direksi Nokep 883-DIR/KPS/10/2012 sebagai suatu aturan hukum yang berlaku surut. Hal ini mengingkari asas hukum bahwa hukum tidak berlaku surut. Menjadi pertanyaan mengapa PT BRI Persero Tbk baru mengeluarkan dasar pengaturan pensiun bagi pekerjanya setelah masa hubungan kerja berakhir. Hal ini menimbulkan suatu pemikiran atas pembenaran fakta yang disampaikan oleh pekerja PT BRI Persero Tbk yang diPHK karena memasuki usia pensiun, bahwa selama hubungan kerja berlangsung belum ada inforrmasi yang terbuka berkaitan dengan hak atas pensiun. Apabila sebelum SK Direksi Nokep 883-DIR/KPS/10/2012 diputuskan, telah ada aturan internal dari PT BRI Persero Tbk, menjadi pertanyaan berikutnya adalah mengapa pekerja tidak mengetahui apabila telah ada aturan internal. Terhadap hal ini, PT BRI Persero Tbk harus dapat membuktikan bahwa telah ada aturan internal PT BRI Persero Tbk mengenai hak atas pensiun.

Kedua, Surat Divisi Kebijakan dan Pengembangan SDM PT BRI Persero Tbk No. B.355-KPS/HBI/10/2012 tanggal 11 Oktober 2012 untuk menginformasikan SK Direksi Nokep 883-DIR/KPS/10/2012 dan Juklaknya kepada pekerja BRI yang di PHK karena mencapai usia pensiun normal tmt 31 Maret 2003 sampai dengan 31 Desember 2011. Fakta yang ada di wilayah Jawa Timur terdapat 1.422 (seribu empat ratus dua puluh dua) pekerja yang di PHK karena memasuki usia pensiuan dari tanggal 30 Maret 2003 sampai dengan 1 Desember 2012. Apa yang menjadi dasar pemikiran SK Direksi Nokep 883-DIR/KPS/10/2012 dalam menetapkan pembatasan pekerja dari hanya terbatas pada pekerja BRI yang di PHK karena mencapai usia pensiun normal tmt 31 Maret 2003 sampai dengan 31 Desember 2011. Keberadaan SK Direksi Nokep 883DIR/KPS/10/2012 belum menunjukkan itikad baik dalam upaya menyelesaikan kasus ini. Bagaimana dengan pekerja yang di PHK karena memasuki usia pensiuan dari tanggal 30 Maret 2003. Bagaimana dengan pekerja yang di PHK karena memasuki usia pensiuan dari tanggal 1 Januari 2012 sampai dengan tanggal 1 Desember 2012. Hal ini perlu dicermati keberadaan SK PT BRI Persero Tbk Nokep: S.15DIR/SDM/3/2003 tanggal 6 Maret 2003, menunjuk tanggal 25 Maret 2003 (bukan 31 Maret 2003).

Ketiga, Subyek hukum yang melakukan hubungan hukum dalam kasus ini adalah PT BRI Persero Tbk 
dan pekerja PT BRI Persero Tbk. PT BRI Persero Tbk berkewajiban memberikan uang pensiun minimal sebesar uang pesangon 2 (dua) kali ketentuan Pasal 156 ayat (2) dan uang penghargaan masa kerja 1 (satu) kali ketentuan Pasal 156 ayat (3), dan uang penggantian hak sesuai ketentuan Pasal 156 ayat (4) kepada pekerja PT BRI Persero Tbk berdasarkan Pasal 167 UU Ketenagakerjaan. Keberadaan Dana Pensiun Lembaga Keuangan (DPLK) BRI dalam kasus ini adalah subyek hukum yang terikat hubungan hukum hanya dengan PT BRI Persero Tbk. Dalam hal ini DPLK BRI adalah pihak ketiga. Hubungan hukum antara PT BRI Persero Tbk dan pihak ketiga (DPLK BRI) tidak dapat mengikat pekerja BRI.

Analisis Substansi SK Nokep 883-DIR/KPS/ 10/2012 terhadap Pasal 167 UU Ketenagakerjaan berdasarkan substansi objek. Objek hukum dari SK Direksi Nokep 883-DIR/KPS/10/2012 (Pasal 1 angka 2) merupakan uang pensiun. PT BRI Persero Tbk telah melakukan pembatasan kriteria uang pensiun adalah penjumlahan dari akumulasi iuran atas beban BRI untuk PPMP berikut pengembangannya yang dikelola oleh Dana Pensiun BRI yang pengembangannya merupakan hasil perhitungan Aktuaria; dan akumulasi iuran atas beban BRI untuk Program Pensiun Iuran Pasti (PPIP) berikut pengembangannya yang dikelola Dana Pensiun Lembaga Keuangan (DPLK).

Ada tiga problem hukum berkaitan substansi obyek. Pertama, berkaitan dengan prosentase sharing dana pensiun, yaitu ikut sertanya pekerja dalam pembayaran iuran atau premi program pensiun. Ketentuan Pasal 1 angka 2 SK Direksi Nokep 883-DIR/KPS/10/2012, mengakibatkan adanya pemahaman yang sesat bahwa iuran program pensiun menjadi beban BRI seratus persen. Hal ini mengingat ketentuan Pasal 1 angka 2 SK Direksi Nokep 883-DIR/KPS/10/2012 tidak menyebutkan keikutsertaan pekerja membayar sebagian iuran program pensiun. Fakta yang ada, pekerja pada masa hubungan kerja sedang berlangsung telah membayar sebagian iuran atau premi program pensiun (Hasil wawancara tidak terstruktur dengan pensiunan PT BRI Persero Tbk, tanggal 22 Oktober 2012). Ketentuan besarnya prosentase sharing dana pensiun, tidak ada di dalam SK Direksi Nokep 883DIR/KPS/10/2012. Hal ini mengakibatkan adanya pemahaman yang sesat bahwa iuran program pensiun menjadi beban BRI seratus persen. Fakta yang ada, pekerja pada masa hubungan kerja sedang berlangsung telah membayar sebagian iuran atau premi program pensiun, yaitu sharing dana pensiun PPMP oleh BRI sebelum tahun 2005 sebesar $61,11 \%$ dan sesudah tahun 2005 sebesar $72 \%$ (Hasil wawancara tidak terstruktur dengan pensiunan PT BRI Persero Tbk, tanggal 22 Oktober 2012). Sesuai fakta, BRI telah menunjukkan kriteria sebagai majikan yang tidak baik, dengan tidak memberikan informasi yang terbuka atas besarnya potongan upah pekerja.

Kedua, berkaitan dengan akumulasi jumlah premi yang telah dibayarkan. Ketentuan Pasal 1 angka 2 SK Direksi Nokep 883-DIR/KPS/10/ 2012, menunjukkan bahwa uang pensiun adalah PPMP (dan pengembangannya) ditambah PPIP (dan pengembangannya). Dalam hal ini harus ada keterbukaan mengenai: berapa jumlah premi atau iuran yang telah dibayarkan oleh BRI; berapa jumlah premi atau iuran yang telah dibayarkan oleh pekerja; berapa jumlah pengembangan PPMP; dan berapa jumlah pengembangan PPIP secara terpisah.

\begin{tabular}{|c|c|c|}
\hline $\begin{array}{c}\text { Berdasarkan } \\
\text { SK No. S.15-DIR/SDM/3/2003 }\end{array}$ & $\begin{array}{c}\text { Berdasarkan } \\
\text { S.6-DIR/SDM/3/2003 }\end{array}$ & $\begin{array}{c}\text { Berdasarkan } \\
\text { Pasal } 90 \text { jo } 94 \text { jo } 157 \text { UU No. } 13 \\
\text { Tahun } 2003\end{array}$ \\
\hline $\begin{array}{l}\text { Upah terdiri atas: Upah dasar; Tunjangan } \\
\text { khusus wilayah; Tunjangan pengobatan } \\
\text { rutin; Tunjangan sewa rumah; dan } \\
\text { tunjangan listrik, telepon, air dan gas. }\end{array}$ & $\begin{array}{l}\text { Upah terdiri atas: Upah } \\
\text { pokok; Tunjangan } \\
\text { premium; Tunjangan } \\
\text { peralihan; Tunjangan } \\
\text { khusus. }\end{array}$ & $\begin{array}{l}\text { Upah (minimal upah minimum) } \\
\text { terdiri atas: Upah pokok }(\min 75 \%) \text {; } \\
\text { dan Tunjangan tetap }(\max 25 \%)\end{array}$ \\
\hline $\begin{array}{l}\text { Tunjangan Tetap: Tunjangan konjungtur; } \\
\text { Tunjangan khusus wilayah; Tunjangan sewa } \\
\text { rumah; Tunjangan pengobatan rutin dan } \\
\text { Tunjangan listrik, telepon, air, dan gas. }\end{array}$ & $\begin{array}{l}\text { Tunjangan Tetap: } \\
\text { Tunjangan premium; dan } \\
\text { Tunjangan peralihan }\end{array}$ & Tunjangan tidak tetap. \\
\hline $\begin{array}{l}\text { Tunjangan Tidak Tetap: Tunjangan } \\
\text { perusahaan; Tunjangan jabatan; Tunjangan } \\
\text { pengangkutan; Tunjangan uang makan. }\end{array}$ & $\begin{array}{l}\text { Tunjangan tidak tetap: } \\
\text { Tunjangan khusus. }\end{array}$ & \\
\hline
\end{tabular}


Ketiga, berkaitan dengan komponen upah. Pasal 6 SK Direksi Nokep 883-DIR/KPS/10/2012 menyatakan bahwa upah dalam perhitungan uang pesangon, uang penghargaan masa kerja dan penggantian hak di PT BRI Persero Tbk ternyata beragam, seperti dalam tergambar dalam tabel.

Dari tabel di atas, maka perlu dicermati kedudukan Tunjangan Khusus, berdasarkan SK No. S.15-DIR/ $\mathrm{SDM} / 3 / 2003$ sebagai tunjangan tetap, tetapi berdasarkan S.6-DIR/SDM/02/2005 sebagai tunjangan tidak tetap. Perubahan tempat sangat mempengaruhi ketepatan upah berdasarkan tinjauan komponennya. Selanjutnya akan dianalisa mengenai kesesuaian upah minimal dari upah pekerja PT BRI Persero Tbk, dan analisa berdasarkan SK No. S.15-DIR/SDM/3/2003, serta akumulasi dari upah dasar, tunjangan konjungtur, tunjangan khusus wilayah, tunjangan pengobatan rutin dan tunjangan sewa rumah; dan tunjangan listrik, telepon, air, dan gas. Serta analisa berdasarkan S.6-DIR/SDM/02/2005, besarnya upah yang terdiri dari upah pokok, tunjangan premium dan tunjangan peralihan telah minimum sebesar upah minimum.

Keikutsertaan pekerja dalam pembayaran iuran atau premi menjadi dasar keberlakuan Pasal 167 ayat (1) atau Pasal 167 ayat (3) UU Ketenagakerjaan. Demikian pula dengan diketahuinya jumlah 4 komponen uang pensiun secara terpisah, menjadi dasar penerapan ketentuan Pasal 167 UU Ketenagakerjaan, menyatakan bahwa: pertama, Pengusaha dapat melakukan pemutusan hubungan kerja terhadap pekerja karena memasuki usia pensiun dan apabila pengusaha telah mengikutkan pekerja pada program pensiun yang iurannya dibayar penuh oleh pengusaha, maka pekerja tidak berhak mendapatkan uang pesangon sesuai ketentuan Pasal 156 ayat (2), uang penghargaan masa kerja sesuai ketentuan Pasal 156 ayat (3), tetapi tetap berhak atas uang penggantian hak sesuai ketentuan Pasal 156 ayat (4); kedua, Dalam hal besarnya jaminan atau manfaat pensiun yang diterima sekaligus dalam program pensiun sebagaimana dimaksud dalam ayat (1) ternyata lebih kecil daripada jumlah uang pesangon 2 (dua) kali ketentuan Pasal 156 ayat (2) dan uang penghargaan masa kerja 1 (satu) kali ketentuan Pasal 156 ayat (3), dan uang penggantian hak sesuai ketentuan Pasal 156 ayat (4), maka selisihnya dibayar oleh pengusaha; ketiga, Dalam hal pengusaha telah mengikutsertakan pekerja dalam program pensiun yang iuran atau preminya dibayar oleh pengusaha dan pekerja, maka yang diperhitungkan dengan uang pesangon yaitu uang pensiun yang premi atau iurannya dibayar oleh pengusaha.

Atas dasar ketentuan Pasal 167 ayat (1), (2) dan (3) beserta penjelasannya, maka kasus ini memenuhi kriteria Pasal 167 ayat (3) UU Ketenagakerjaan, bahwa: Pertama, PT BRI Persero Tbk telah mengikutsertakan pekerja dalam program pensiun yang iuran atau preminya dibayar oleh pengusaha dan pekerja. Kedua, Hak pekerja adalah uang pesangon yaitu uang pensiun yang premi atau iurannya dibayar oleh pengusaha. Ketiga, Besarnya hak atau nilai yang diterima oleh pekerja adalah minimal sama dengan: uang pesangon 2 (dua) kali ketentuan Pasal 156 ayat (2) dan uang penghargaan masa kerja 1 (satu) kali ketentuan Pasal 156 ayat (3), dan uang penggantian hak sesuai ketentuan Pasal 156 ayat (4). Keempat, PT BRI Persero Tbk telah merumuskan sendiri besarnya uang pensiun (Pasal 2 SK Nokep. 883-DIR/KPS/10/2012). Uang pensiun adalah akumulasi PPMP dan PPIP berikut pengembangannya. Kelima, Ketentuan Pasal 2 SK Nokep. 883-DIR/ KPS/10/2012 harus diberikan penjelasan yang lebih terbuka, mengenai: 1 . Besarnya prosentase pembagian pembayaran premi antara yang ditanggung PT BRI (Persero) Tbk dan pekerja; 2. Jumlah premi yang telah dibayarkan oleh PT BRI (Persero) Tbk tidak dapat diinterpretasikan dengan nilai yang telah dibayarkan ditambah pengembangannya; 3. Hubungan hukum yang terjadi antara PT BRI (Persero) Tbk dan pekerja hanya terbatas pada sharing (berdasar pembagian prosentase yang pasti) pembayaran premi; 4. Pengelolaan lebih lanjut atas premi yang telah dibayarkan oleh PT BRI (Persero) Tbk adalah perbuatan hukum yang dilakukan oleh PT BRI (Persero) Tbk dengan Pihak ketiga. Tidak ada hubungannya dengan pekerja, sehingga tidak dapat menjadi bagian yang diperhitungkan sebagai besaran uang pensiun. Keenam, Dasar perhitungan uang pesangon 2 (dua) kali ketentuan Pasal 156 ayat (2) dan uang penghargaan masa kerja 1 (satu) kali ketentuan Pasal 156 ayat (3), dan uang penggantian hak sesuai ketentuan Pasal 156 ayat (4) adalah upah. Ketujuh, Upah adalah hak pekerja yang diterima dan dinyatakan dalam bentuk uang sebagai imbalan dari pengusaha atau pemberi kerja kepada pekerja yang ditetapkan dan dibayarkan menurut suatu perjanjian kerja, kesepakatan, atau peraturan perundang-undangan, termasuk tunjangan bagi pekerja dan keluarganya atas suatu pekerjaan dan/atau jasa yang telah atau akan dilakukan (Pasal 1 angka 30 UU Ketenagakerjaan). Kedelapan, Komponen upah minimal adalah upah 
pokok dan tunjangan tetap. Besar tunjangan tetap maksimal 25 \% (Pasal 12 ayat (2) PP Nomor 8 Tahun 1981). Kesembilan, Pengusaha dilarang membayar upah lebih rendah dari upah minimum (Pasal 90 ayat (1) UU Ketenagakerjaan). Kesepuluh, Pelanggaran Pasal 90 ayat (1) UU Ketenagakerjaan adalah kejahatan dengan ancaman sanksi pidana penjara 1-4 tahun, dan/atau denda Rp. 100-400 juta (Pasal 90 ayat (1) jo Pasal 185 UU Ketenagakerjaan).

\section{PENUTUP}

\section{Kesimpulan}

Pekerja yang telah di PHK karena memasuki usia pensiun dilindungi oleh ketentuan Pasal 167 UU Ketenagakerjaan. PT BRI Persero Tbk telah mengikutsertakan pekerja dalam program pensiun yang iuran atau preminya dibayar oleh PT BRI Persero Tbk dan pekerja, maka yang diperhitungkan dengan uang pesangon yaitu uang pensiun yang premi atau iurannya dibayar oleh PT BRI Persero Tbk. Kedudukan SK Direksi Nokep 883-DIR/KPS/10/2012 sebagai dasar pemberian hak pensiun bagi pekerja PT BRI Persero Tbk adalah bertentangan dengan ketentuan Pasal 167 ayat (3) UU Ketenagakerjaan.

\section{Rekomendasi}

PT BRI Persero Tbk harus menetapkan besaran prosentase pembagian pembayaran premi pensiun antara PT BRI Persero Tbk dan pekerja. PT BRI Persero Tbk harus dapat menetapkan jumlah premi yang telah dibayar oleh PT BRI Persero Tbk tanpa ditambah nilai pengembangan. PT BRI Persero Tbk harus dapat menetapkan komponen besaran upah pekerja dalam tiga kelompok yaitu upah pokok (minimal $75 \%$ ) tunjangan tetap (maksimal 25\%) dan tunjangan tidak tetap. Besar upah pokok ditambah tunjangan tetap minimal upah minimum, harus diperhitungkan kembali kepada semua pekerja sejak tahun 2003. Hak pekerja karena usia pensiun adalah minimal uang pesangon 2 (dua) kali ketentuan Pasal 156 ayat (2) dan uang penghargaan masa kerja 1 (satu) kali ketentuan Pasal 156 ayat (3), dan uang penggantian hak sesuai ketentuan Pasal 156 ayat (4)

\section{DAFTAR PUSTAKA}

\section{Buku:}

Hadjon, Philipus M. 2007. Perlindungan Hukum bagi Rakyat Indonesia (Suatu Studi tentang Prinsipprinsipnya, Penanganannya oleh Pengadilan dalam Lingkungan Peradilan Umum dan Pembentukan Peradilan Administrasi), Jakarta: Peradaban.

Kamal, Miko. Konsep Corporate Governance di Indonesia: Kajian atas Kode Corporate Governance. Jurnal Manajemen Teknologi Vol. 10 No. 2 Tahun 2011.

Paton, G.W. 1964. A Text-Book of Jurisprudence. Oxford: Oxford University Press.

Rasjidi, Lili. 1988. Filsafat Hukum, Apakah Hukum Itu? Bandung: Remadja Karya.

The Merriam Webster Dictionary. 2004. Merriam Webster Incorporated.

Wicaksono, A. 2009. Corporate Governance of Stateowned Enterprises: Investment Holding Structure of Government-Linked Companies in Singapore and Malaysia and Applicability for Indonesian State-Owned Enterprises. Unpublished Doctoral Dissertation at the University of St. Gallen, Graduate School of Business Administration, Economics, Law and Social Science (HSG).

\section{Peraturan Perundang-undangan:}

Undang-Undang Dasar 1945.

Undang-Undang Republik Indonesia Nomor 14 Tahun 1967 tentang Pokok-Pokok Perbankan.

Undang-Undang Republik Indonesia Nomor 13 Tahun 1968 tentang Bank Sentral.

Undang-Undang Republik Indonesia Nomor 11 Tahun 1969 tentang Pensiun Pegawai dan Pensiun Janda/Duda Pegawai.

Undang-Undang Republik Indonesia Nomor 13 Tahun 2003 tentang Ketenagakerjaan (Lembaran Negara Tahun 2003 Nomor 39, Tambahan Lembaran Negara Tahun 2003 Nomor 4279).

PERPU Nomor 41 Tahun 1960 tentang Bank Koperasi Tani dan Nelayan (BKTN).

Peraturan Pemerintah Republik Indonesia Nomor 1 Tahun 1946 tentang Pembentukan BRI.

Peraturan Pemerintah Republik Indonesia Nomor 21 Tahun 1992 Status BRI Berubah menjadi Perseroan Terbatas.

Penetapan Presiden Republik Indonesia Nomor 9 Tahun 1965 tentang Pembentukan Bank Indonesia Urusan Koperasi Tani dan Nelayan.

Penetapan Presiden (Penpres) Republik Indonesia Nomor 17 Tahun 1965 tentang Bank Negara Indonesia. 
SK Direksi Nokep 883-DIR/KPS/10/2012 tentang Penyelesaian kewajiban perusahaan terhadap pekerja yang berakhir hubungan kerjanya karena mencapai usia pensiun normal sebagai implementasi dari Undang-Undang Nomor 13 Tahun 2003.

SK PT BRI Persero Tbk Nokep: S.15-DIR/SDM/3/ 2003 tanggal 6 Maret 2003

Surat Divisi Kebijakan dan Pengembangan SDM PT BRI Persero Tbk No. B.355-KPS/HBI/10/2012 tanggal 11 Oktober 2012 untuk menginformasikan SK Direksi Nokep 883-DIR/KPS/10/2012 dan Juklaknya kepada pekerja BRI yang di PHK karena mencapai usia pensiun normal terhitung mulai tanggal 31 Maret 2003 sampai dengan 31 Desember 2011.

Surat Majelis Mediator Hubungan Industrial Disnakertransduk Propinsi Jawa Timur No. 560/434/106.04/2013 tanggal 9 Oktober 2013.

Putusan Mahkamah Agung Nomor 568K/Pdt.Sus/ 2009.

The Universal Declaration of Human Rights.

\section{Website:}

Berita Resmi Statistik No. 78/11/Th. XVI, 6 November 2013.

http://www.bps.go.id/tab_sub/view.php?tabel=1\&id_ subyek $=12$, diunduh hari Senin, 2 Desember 2013, jam 10.14 WIB.

http://www.rumahkiri.net/index.php, diunduh pada Selasa, 12 Maret 2012, jam 20.08 WIB.

http://www.silaban.net/2006/05/10/dialog-b, diunduh pada Selasa 12 Maret 2012, jam 21.03 WIB.

http://www.indosiar.com/news/fokus/511858, diunduh pada Selasa, 13 Maret 2012, jam 10.08 WIB.

http://id.wikipedia.org/wiki/Bank_Rakyat_Indonesia, diunduh hari Senin, 2 Desember 2013, jam 10.44 WIB. http://www.ir-bri.com/, diunduh hari Minggu, 1 Desember 2013, jam 20.44 WIB.

http://media.corporate-ir.net/media_files/IROL/14/ 148820/AR_BRI_English_2012.pdf. diunduh hari Senin, 2 Desember 2013, jam 10.34 WIB.

http://www.antikorupsi.org.id/content/sidang-kasuskorupsi-pt-cgn-selamatkan-dana-pensiun-bankmandiri-iii, diunduh hari Kamis, 10 Oktober 2013, jam 09.38 WIB.

http://kennortonhs.wordpress.com/2007/08/02/sejumlahpensiunan-bri-tuntut-pesangon/, diunduh hari Kamis, 10 Oktober 2013, jam 10.38 WIB.

http://jakarta.okezone.com/read/2013/09/04/500/ 860896/redirect, diunduh hari Kamis, 10 Oktober 2013, jam 09.40 WIB.

http://www.jpnn.com/read/2013/09/04/189305/BRIDianggap-Profesional-Penuhi-Hak-Pensiunan, diunduh hari Senin, 2 Desember 2013, jam 10.04 WIB.

http://m.news.viva.co.id/news/read/429287-gelardemo-ada-apa-dengan-pensiunan-bri, diunduh hari Senin, 2 Desember 2013, jam 11.03 WIB.

http://www.beritasatu.com/nasional/113436-demopensiunan-bri-tetap-pegang-keputusan-ma.html, diunduh hari Selasa, 3 Desember 2013, jam 10.24 WIB.

http://news.detik.com/surabaya/read/2013/03/19/ 120336/2197760/466/pensiunan-demo-inilahpenjelasan-manajemen-bri, diunduh hari Senin, 2 Desember 2013, jam 12.04 WIB.

http://www.sbm.itb.ac.id/wp-content/uploads/2011/ 08/3-mikro-kamal.pdf, diunduh hari Senin, 2 Desember 2013, jam 09.35 WIB.

Wawancara tidak terstruktur dengan pensiunan PT BRI Tbk wilayah Jawa Timur tanggal 10 Oktober 2013.

Wawancara tidak terstruktur dengan pensiunan PT BRI Persero Tbk tanggal 22 Oktober 2012. 